\title{
Physical habitat and water chemistry changes induced by logging and gold mining in French Guiana streams
}

\author{
N. Dedieu ${ }^{(1),(2),(3), \star}$, L. Allard(1),(2),(4), R. Vigouroux ${ }^{(2)}$, S. Brosse ${ }^{(1),(4)}$, \\ R. Céréghino ${ }^{(1),(3)}$
}

Received April 18, 2014

Revised July 29, 2014

Accepted July 29, 2014

\section{ABSTRACT}

Key-words: neotropical steams, headwaters, reference conditions, deforestation, gold mining

\begin{abstract}
Understanding the effects of disturbances on the physical-chemical quality of ecosystems is a crucial step to the development of ecosystem assessment tools. 95 sampling sites distributed among 4 categories of disturbance, i.e.: reference, logging, formerly and currently gold mining, were characterized using stream physical and chemical variables. Our hypotheses were: (i) logging and gold mining activities primarily affect the physical habitat structure of streams and (ii) both have an effect on chemical environments through nutrient and/or fine particulate resuspension. We demonstrate that physical variables describing the river bottom, and suspended solids discriminate both current and formerly gold mined sites from reference sites, while, whatever the type of impact encountered, nutrient concentrations do not prove relevant to measure human impacts. To understand distribution patterns of aquatic organism across FG, future research should thus aim at examining the match between physicalchemical and biological classifications of small streams under reference and impacted conditions.
\end{abstract}

\section{RÉSUMÉ}

Impact de l'orpaillage et de la déforestation sur la chimie de l'eau et l'habitat physique dans les petits cours d'eau de Guyane Française

\author{
Mots-clés : \\ cours d'eaux \\ néotropicaux, \\ tête \\ de bassin, \\ condition \\ de référence, \\ déforestation, \\ orpaillage
}

Comprendre l'effet des perturbations sur les paramètres physico-chimiques de qualité des eaux est une étape essentielle du développement d'outils d'évaluation. Les petits cours d'eau de Guyane Française représentent $70 \%$ du réseau hydrographique du département, et sont soumis à de fortes pressions (déforestation et orpaillage). Nous supposons que l'exploitation aurifère et forestière affecte principalement la structure physique de l'habitat et que ces deux types d'exploitation ont une influence sur le compartiment chimique par la modification du flux de nutriments et/ou la remise en suspension de particules fines. 95 sites répartis en quatre catégories de perturbation (référence, exploitation forestière, orpaillage actuel et ancien) ont été caractérisés par des variables physico-chimiques. Nous avons démontré que les variables physiques différencient les sites orpaillés anciens et récents. Les concentrations en nutriments ne sont pas significativement modifiées par les impacts humains. Afin de mieux comprendre les patrons de distribution des organismes aquatiques de Guyane Française, le lien entre la physicochimie des cours d'eau et les communautés biologiques inféodées en situation de référence et perturbée doit être étudié.

(1) Université de Toulouse, UPS, 31062 Toulouse, France

(2) Hydreco Guyane, Laboratoire environnement de petit Saut, BP 823, 97388 Kourou Cedex, Guyane Française

(3) CNRS, EcoLab (UMR-CNRS 5245), 118 Route de Narbonne, 31062 Toulouse, France

(4) CNRS, Université Paul Sabatier; UMR5174 EDB, 31062 Toulouse, France

^ Corresponding author: nicolas.dedieu@hydrecolab.com 


\section{INTRODUCTION}

Under most water management policies, ecosystem health is defined in terms of similarity to a near-pristine, undisturbed state (Bailey et al., 2003). In practice, predictions of the physicalchemical and/or biological conditions to be expected under undisturbed conditions in any given geographic area are based on the classification of river sites. By knowing what set of environmental conditions should be encountered at undisturbed (or least impacted) sites, one can then estimate the degree to which impacted sites are altered by human activity (Bennett et al., 2011). In addition, physical-chemical classifications of rivers provide a template against which changes in biological diversity within watersheds can be interpreted in relation to natural variability and anthropogenic impacts (Van Sickle and Hughes, 2000).

Recent studies in temperate areas have prompted a large amount of characterizations of reference and impacted physical-chemical environments (e.g., Tudesque et al., 2008). However, differences in bioclimatic, biogeographic and geomorphological conditions preclude the transposition of current typological schemes to EU's overseas regions (see Touron-Poncet et al., 2014 for a rationale), while limited scientific effort has been directed at typifying rivers in overseas Europe in terms of physical-chemical (and biological) patterns. Therefore, as a prerequisite to any methodological development, there is a pressing need to collect environmental information in a standardized manner so that fundamental data can be analyzed in an integrated way.

French Guiana $(\mathrm{FG})$ is an overseas region of France located on the northern coast of South America. About $96 \%$ of its surface area (over $82000 \mathrm{~km}^{2}$ ) is covered by equatorial forest, which partly belongs to a recently-created National Park. The Guianese primary forest remains one of the least impacted of the World, however, gold mining and timber have strong impacts upon river ecosystems. Specifically, the annual gold output in the area is 60 times higher than 25 years ago (Hammond et al., 2007). After the prospection of large rivers, gold industries are now focusing on smaller inland streams (Cleary, 1990; Hammond et al., 2007). Small streams (from headwaters to rivers with depth $<1 \mathrm{~m}$ and width $<10 \mathrm{~m}$ ) represent $70 \%$ of all running waters in FG. Most of small streams are located in forested areas and exhibit high ecological quality; some if not most of them have never been impacted by any human activity. In light of recent economic development, our ability to predict both reference conditions and ecosystem responses to landscape alterations will determine the success of future management actions. We relied on extensive characterizations of stream physical (particle size, substratum heterogeneity) and chemical conditions (e.g., nitrogen, phosphorus) at 95 sampling sites distributed over 95 streams and representing 4 categories of disturbance: reference (unimpacted), deforestation, ancient gold mining, and ongoing gold mining. First, we tested if impacted sites are randomly located within the river continuum or if they are characterized by particular local physical features that distinguish them from the references. Our hypothesis was that, at any given location within a stream system, gold mining and deforestation primarily affect the physical habitat structure and/or heterogeneity. Second, we tested differences in chemical variables among site categories. Assuming that both deforestation and gold mining affect chemical environments through nutrient and/or fine particulate runoff/resuspension, we expected that sediment resuspension due to gold mining would result in harsher shifts in instream environmental conditions.

\section{MATERIAL AND METHODS}

\section{> STUDY AREA}

This study was conducted in French Guiana (surface area $=83534 \mathrm{~km}^{2}$ ), East Amazonia, from September 2011 to December 2012. The climate is tropical moist with 3000-3400 mm of yearly precipitation mainly distributed over $\mathbf{2 8 0}$ days. There is a major drop in rainfall (dry season) between September and December and another shorter and more irregular dry period in March. The maximum monthly temperature averages $33.5^{\circ} \mathrm{C}\left(32.1-35.8^{\circ} \mathrm{C}\right)$, and the 


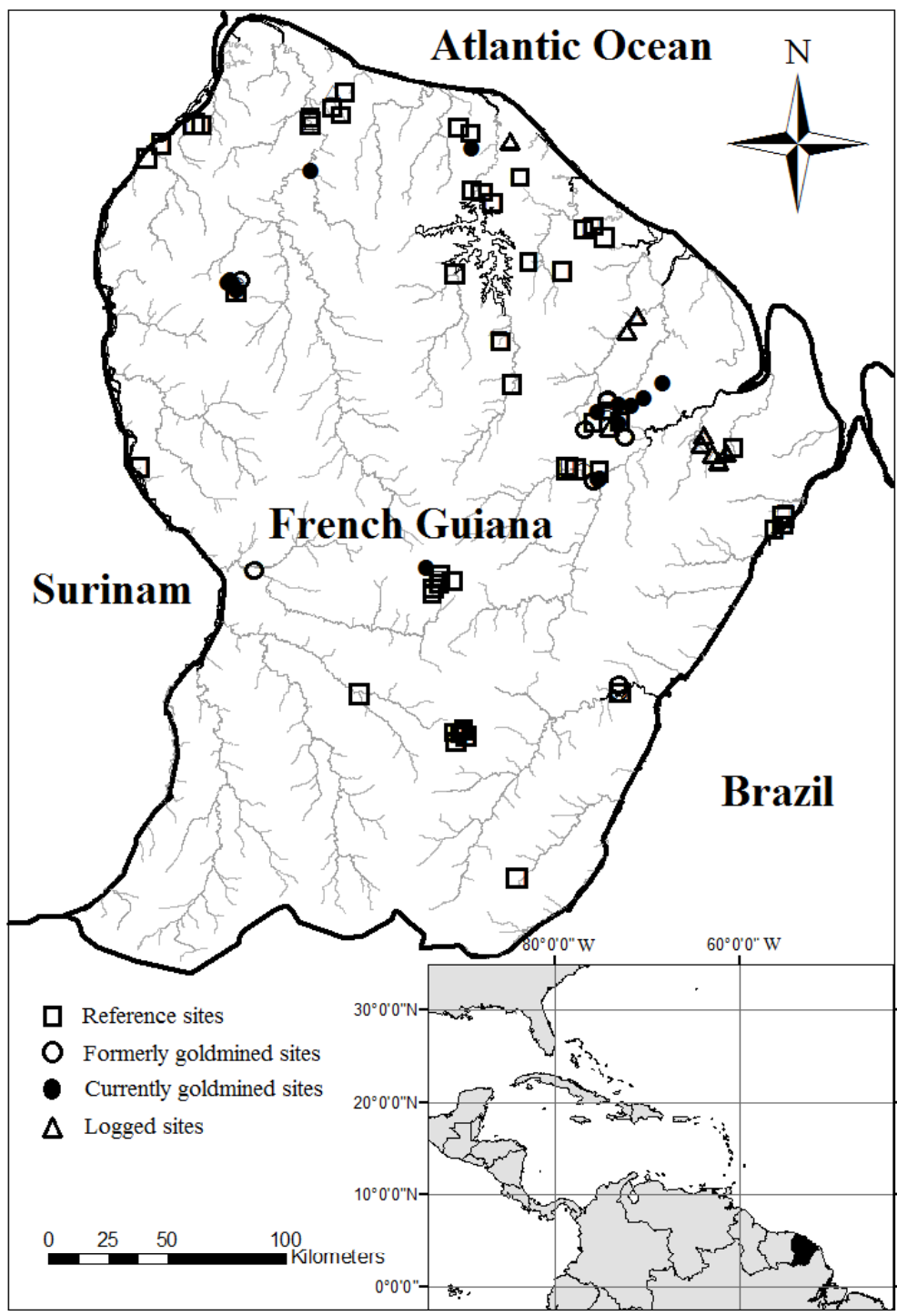

Figure 1

Map of French Guiana showing the main rivers and the location of the sampling sites.

monthly minimum averages $20.3^{\circ} \mathrm{C}\left(19.7-21^{\circ} \mathrm{C}\right)$. French Guiana's stream systems are organized around seven large rivers (Maroni, Kourou, Mana, Sinnamary, Comté, Approuagues, and Oyapock rivers); however, the "small streams" sampled in this study (water depth $<1 \mathrm{~m}$; stream width $<10 \mathrm{~m}$ ) represent ca. $80000 \mathrm{~km}$ in total length, i.e. $70 \%$ of all running waters in the region. We did not considered larger streams and rivers to focus on comparable ecosystems located in the upstream part of the river continuum.

\section{> SAMPLING SITES AND ENVIRONMENTAL VARIABLES}

Our 95 sampling sites were distributed over 95 small streams belonging to FG's main river basins (Figure 1). It should be noted however that the sampling effort was higher in the Northern part of FG, due to the difficulty to access southern FG. In this specific area covered by dense rainforest and without road networks, complex logistics limited our ability to sample a larger number of sites. We thus managed to collect some samples from the main southern river basins (Figure 1). All sites were sampled during the dry season in 2011 and 2012 (September-December). Indeed, pollution is detected less efficiently during high 
flows because of dilution. In addition, most remote sites cannot be reached (and therefore monitored) during the rainy season. Each site was sampled once, and the sites sampled in 2012 are hence distinct from those sampled in 2011. Based on expert knowledge and field observations, sampling sites were categorized into four a priori groups corresponding to four types of anthropogenic pressure. Reference sites (Ref, $n=57$ ) were defined as sites not subjected to anthropogenic impacts such as gold mining, deforestation, chemical pollution, agricultural or urban runoff. Deforested sites were subjected to logging for wood products and timber (Log, $n=15)$, under the supervision of the National Forest Office (ONF). The ONF manages a sustainable logging industry based on strict plans intended to minimize impacts on the environment. The remaining sites were formerly subjected to gold mining but no longer exploited (Fog, abandoned mining $n=9$ ), or currently subject to gold mining (Cug, $n=14$ ). Either formerly or currently gold mined sites refer to illegal gold mining activity. "Illegal" mining refers here to so-called "informal" mining, i.e., small-scale traditional (or artisanal) mining which also occurs in most South American countries (Hammond et al., 2007). Mercury is used for gold amalgamation during the mining process, and about $30 \%$ of the mercury is released into the river. Mercury concentration in the water column is however insignificant (see Coquery et al., 2003; Maury-Brachet et al., 2006 for documented cases in FG). In addition, the effects of heavy metals on the composition of biological communities expected to form Biological Quality Elements in subsequent developments are not obvious (De Jonge et al., 2008). Although mercury was not taken into account in our study, it should be noted however that river sediments have a strong adsorption capacity for heavy metals (Pfeiffer et al., 1989; Roulet et al., 1999) and may certainly be a relevant parameter to quantify the impact of gold mining. Mercury can subsequently accumulate in plant and animal tissues before entering food chains - in French Guiana some concentrations in edible parts of locally consumed fish can surpass the advisory level for human consumption, thus forming a key concern for human health (Durrieu et al., 2005).

Stream scale variables, namely elevation above sea level, distance from the source, and slope were obtained from Geographic Information System (GIS, ESRI ArcGis 10). These variables characterise the location of sampling sites within the upstream-downstream river continuum. Site scale variables were chosen to describe the heterogeneity of riverbed substrate and habitat availability at each site. They were recorded directly in the field and accounted for the percentage composition of organic and mineral substrate types, using the standardized protocol by Souchon et al. (2000). These variables included: \%leaf litter (Litt), \%submerged roots on the banks (Bank), \%submerged vegetation, mostly macrophytes (Macr), \%woody debris (Wood), \%Silt, \%Sand (particle size $<2 \mathrm{~mm}$ ), \%Gravel (Grav 2-25 mm), \%coarse substratum (Coar $>25 \mathrm{~mm}$ ). Coarse substrates being scarce in French Guiana, this category of mineral substrate included pebbles, boulders, and/or rocky outcrops. In addition, we recorded the stream width (Widt, $\mathrm{m}$ ) and water depth (Dept, $\mathrm{m}$ ). The forest canopy coverage (Fore) was evaluated visually, from 0 to $100 \%$ (Table I). We also measured chemical variables accounting for the chemical impairment of stream ecosystem $\left(\mathrm{PO}_{4}^{3-}\right.$ and $\left.\mathrm{NO}_{3}^{-}\right)$by human activities and for the transport of solids (Total Suspended Solid and Turbidity) (Table II). Turbidity was measured directly in the field using an Eutech Instruments Turbidimeter (TN-100). Other chemical analyses were carried out at Hydreco Laboratory, Petit-Saut, based on water samples taken at each site and immediately frozen. Chemical analyses followed standard methods summarized in AFNOR (2000-2005).

\section{> DATA ANALYSIS}

We first used a Principal Component Analysis (PCA) to ordinate the sites according to topological and physical variables, and to bring out potential shifts in physical conditions following anthropogenic disturbance. Prior to analysis, continuous variables were log-transformed, and discrete variables expressed in percentages were Arcsin-transformed. Plots of the first two ordination axes usually capture most of the variance and consequently contain most of the information that is likely to be interpretable (Waite et al., 2000). Neighbouring sites 
Table I

Environmental variables used to describe the four streams category (Ref : reference; Log; logging; Fog: formerly gold mined; Cug: current gold mined). Values indicate mean $\pm S D$.

\begin{tabular}{|l|c|c|c|c|c|c|}
\cline { 2 - 7 } \multicolumn{1}{l|}{} & code & unit & Ref & Log & Fog & Cug \\
\hline $\begin{array}{l}\text { Slevation scale variables } \\
\text { Distance from }\end{array}$ & Elev & m a.s.l. & $131.3 \pm 153.7$ & $57.2 \pm 18.1$ & $80.1 \pm 36.3$ & $90.8 \pm 24.9$ \\
headwater source & Dist & $\mathrm{km}$ & $3.3 \pm 3.8$ & $1.9 \pm 2.4$ & $3.6 \pm 2.6$ & $5.61 \pm 3.4$ \\
Slope & Slop & $\%$ & $4.7 \pm 3.6$ & $4.7 \pm 3.4$ & $4.7 \pm 3.19$ & $3.84 \pm 2.6$ \\
$\quad$ Site scale variables & & & & & & \\
Bank & Bank & $\%$ & $12.1 \pm 13.2$ & $14.1 \pm 12.1$ & $9.2 \pm 7.2$ & $7.79 \pm 5.4$ \\
Macrophyte & Macr & $\%$ & $3.1 \pm 17.4$ & $3.7 \pm 13.7$ & $2.2 \pm 6.5$ & $0.83 \pm 2.7$ \\
Litter & Litt & $\%$ & $24.1 \pm 19.8$ & $24.1 \pm 23.9$ & $16.7 \pm 19.8$ & $25.5 \pm 31.3$ \\
Woody debris & Wood & $\%$ & $14.1 \pm 12.9$ & $20.9 \pm 22.3$ & $13.2 \pm 11.6$ & $7.26 \pm 7.9$ \\
Silt & Silt & $\%$ & $11.9 \pm 18.1$ & $16.3 \pm 17.5$ & $21.7 \pm 12.3$ & $26.2 \pm 27.7$ \\
Sand & Sand & $\%$ & $47.2 \pm 31.9$ & $49.5 \pm 24.7$ & $26 \pm 28.17$ & $16.4 \pm 20.4$ \\
Gravel & Grav & $\%$ & $20.7 \pm 22.9$ & $11.4 \pm 15.4$ & $35.7 \pm 27.8$ & $30.7 \pm 31.6$ \\
Coarse substratum & Coar & $\%$ & $19.6 \pm 25.9$ & $12.7 \pm 15.4$ & $26.6 \pm 25.5$ & $26.7 \pm 27.8$ \\
Width & Widt & $\mathrm{cm}$ & $379.9 \pm 231.5$ & $429.3 \pm 271.2$ & $393.6 \pm 198.7$ & $394.3 \pm 187.5$ \\
Depth & Dept & $\mathrm{cm}$ & $25.5 \pm 11.9$ & $26.7 \pm 14.2$ & $23.1 \pm 7.9$ & $27.9 \pm 13.3$ \\
Forest coverage & Fore & $\%$ & $74.8 \pm 16.3$ & $55.1 \pm 28.3$ & $57 \pm 27.4$ & $64.6 \pm 23.6$ \\
\hline
\end{tabular}

\section{Table II}

Chemical variables used to assess human disturbance on the four streams category (Ref: Reference; Log: logging; Fog: formerly gold mined; Cug: current gold mined). Values indicate mean $\pm S D$.

\begin{tabular}{|l|c|c|c|c|c|}
\hline Chemical variables & unit & Ref & Log & Fog & Cug \\
\hline Turbidity & NTU & $5.31 \pm 22.5$ & $5.51 \pm 11.1$ & $32.5 \pm 93.4$ & $27.6 \pm 43.9$ \\
$\mathbf{N O}_{3}^{-}$ & $\mathrm{mg} / \mathrm{L}$ & $0.31 \pm 0.16$ & $0.25 \pm 0.21$ & $0.34 \pm 0.08$ & $0.25 \pm 0.15$ \\
$\mathbf{P O}_{4}^{3-}$ & $\mathrm{mg} / \mathrm{L}$ & $0.04 \pm 0.02$ & $0.04 \pm 0.05$ & $0.02 \pm 0.02$ & $0.02 \pm 0.02$ \\
Total suspended solid & $\mathrm{mg} / \mathrm{L}$ & $6.1 \pm 12.8$ & $8.4 \pm 12.9$ & $9.9 \pm 14.4$ & $60.4 \pm 155.4$ \\
\hline
\end{tabular}

in the scatterplots were expected to define areas with similar physical environments. Conversely, sites having a large distance to each other were expected to be distant in the feature space, according to environmental characterization. In order to compare distributions of sites according to disturbance types, a Kruskal-Wallis (KW) test was performed on the site coordinates of the two first axes of the PCA. To further bring out relationships between water chemistry, local environments and disturbance, significant differences among a priori groups were also tested using Kruskal-Wallis tests on the raw values of measured parameters. Then, significant differences in physical characteristic between a priori groups of sites (Ref, Log, Fog, Cug) were further assessed using Wilcoxon tests.

As different sites were sampled in 2011 and 2012, the sampling year was not informative and we hence pooled the two years data. All computations were performed using the R Software (R Development Core Team, 2003), the ADE-4 (Thioulouse et al., 1997) and Vegan (Oksanen et al., 2013) package.

\section{RESULTS}

Eigenvalues for axis 1 and 2 of the PCA were 3.43 and 2.26, respectively (Figure 2a). The first and second axes explained $24.53 \%$ and $16.7 \%$ of the overall variance, respectively. The distribution of sampling sites in the scatterplot did not show clear clumps according to environmental characteristics, but rather displayed a predictable, upstream to downstream gradient. Axis 1 thus displayed a gradient of elevation, slope and substratum size (from high (left) to low (right)). These parameters are related to the river competence (i.e. the maximum 


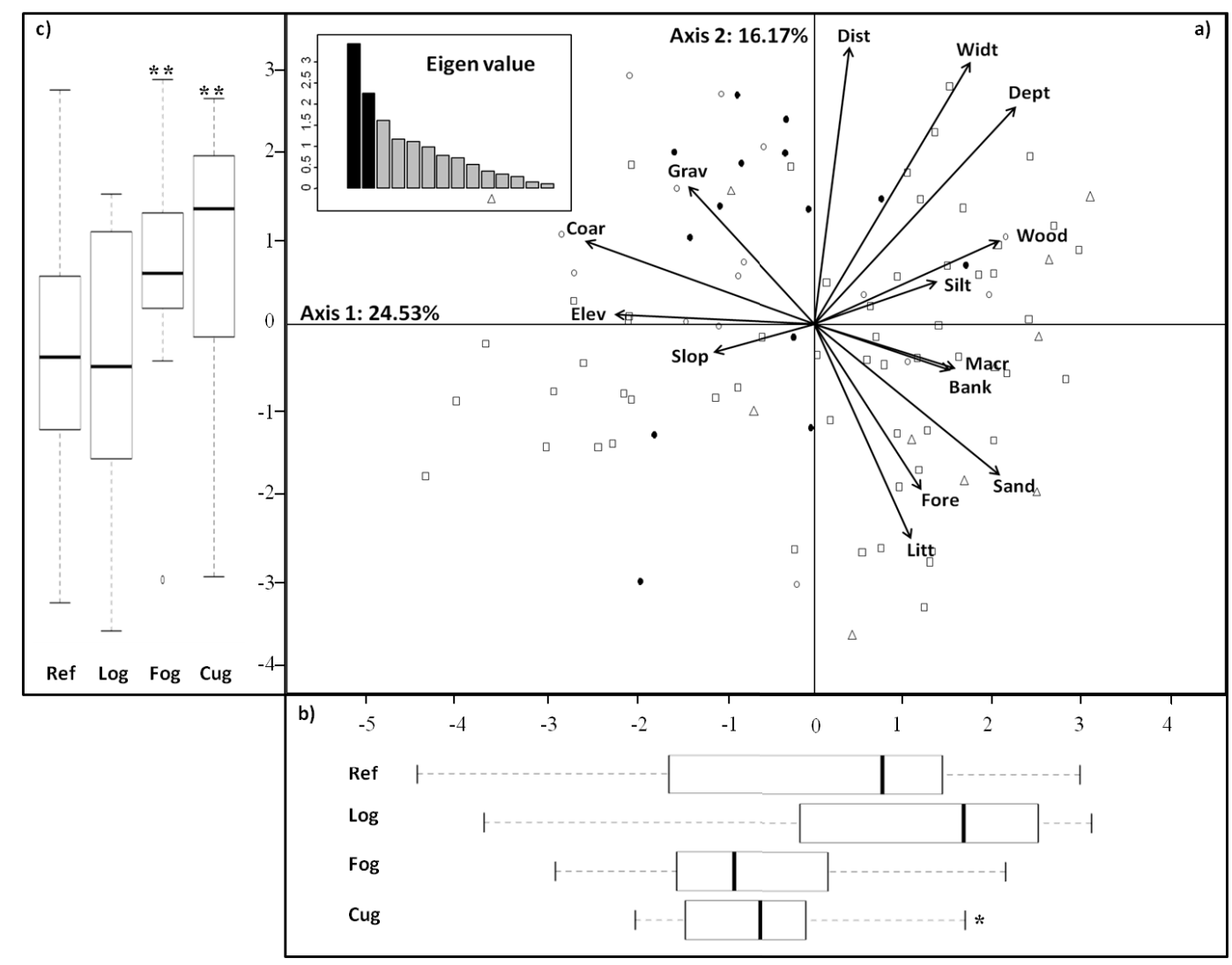

Figure 2

(a) Principal Component Analysis (PCA) biplot showing the distribution of the 95 sites according to environmental variables (see table I for acronyms). Rectangles: reference sites; triangles: logged sites; open circles: formerly gold mined sites and filled circles: currently gold mined sites. (b) Boxplots of the coordinates of the sites on the first axis. (c) Boxplots of coordinates of the sites on the second axis. Ref: reference sites; Log: logged sites; Fog: formerly gold mined sites; Cug: currently gold mined sites. ${ }^{*}: p$-value $<0.1 ;{ }^{* * *}: p$-value $\left.<0.01\right)$

size or weight of material a river can transport). Axis 2 accounted for stream width and depth, and distance from source (from high (upper area) to low (down)).

Sites subjected to current and former gold mining were mostly distributed along axis 2 , while sites subjected to logging were distributed along axis 1 . Only reference sites and sites subjected to current gold mining differed significantly in their distribution along axis 1 (Figure 2b), currently exploited sites being more concentrated in the upstream areas. When the distribution of sites was examined along axis 2 (Figure 2c), both formerly and currently gold mined sites differed from other sites, while reference sites and sites subjected to logging did not show significantly different distributions.

Stream scale variables showed significant differences between impairment categories. The mined sites had coarser substrates than the references and logged sites, as shown by a significant difference in the percentage composition of mineral particles. Significant differences were found in \%sand (KW-chi-square $=15.3776, d f=3, p$-value $=0.001521)$, \%silt (KW-chisquare $=12.2781, d f=3, p$-value $=0.006489)$ and $\%$ gravel $(\mathrm{KW}$-chi-square $=7.6945, d f=3$, $p$-value $=0.04277$ ). Such a difference between reference and mined sites holds true for both the formerly and currently gold mined sites.

Considering chemical variables, neither $\mathrm{PO}_{4}^{3-}$ and $\mathrm{NO}_{3}^{-}$(Figures 3 and $3 \mathrm{~b}$ ), nor suspended solids and turbidity (Figures $3 \mathrm{c}$ and $3 \mathrm{~d}$ ) showed significant differences between reference sites and sites subjected to logging. Gold mining did not alter $\mathrm{PO}_{4}^{3-}$ and $\mathrm{NO}_{3}^{-}$concentrations (Figures $3 a$ and $3 b$ ), however, stream turbidity values (Figure $3 d$ ) were significantly different 

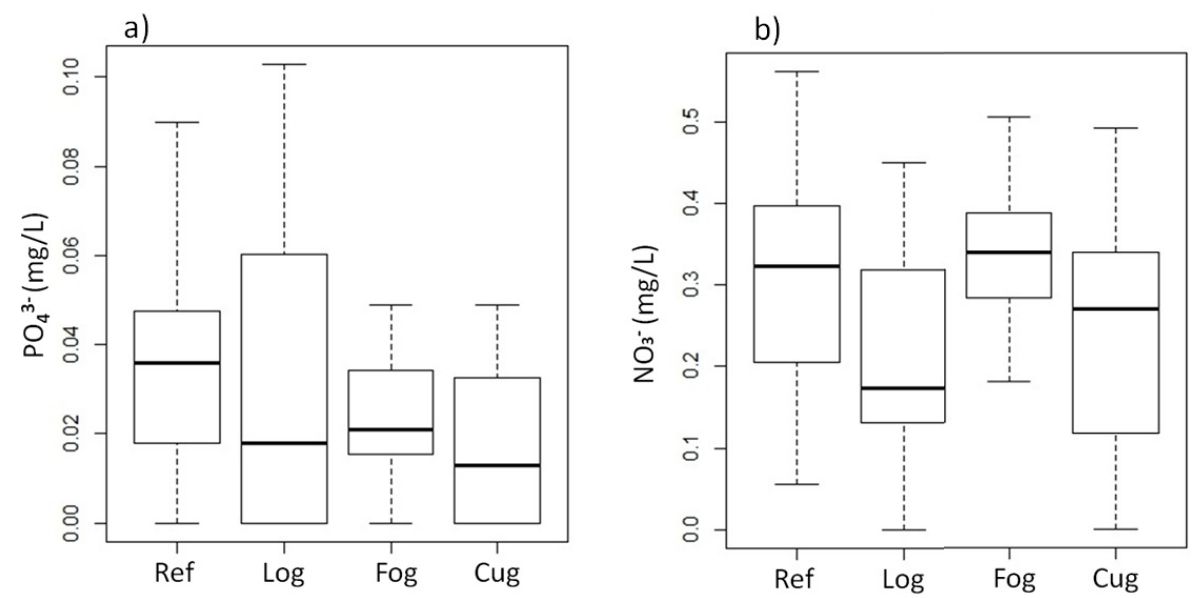

d)
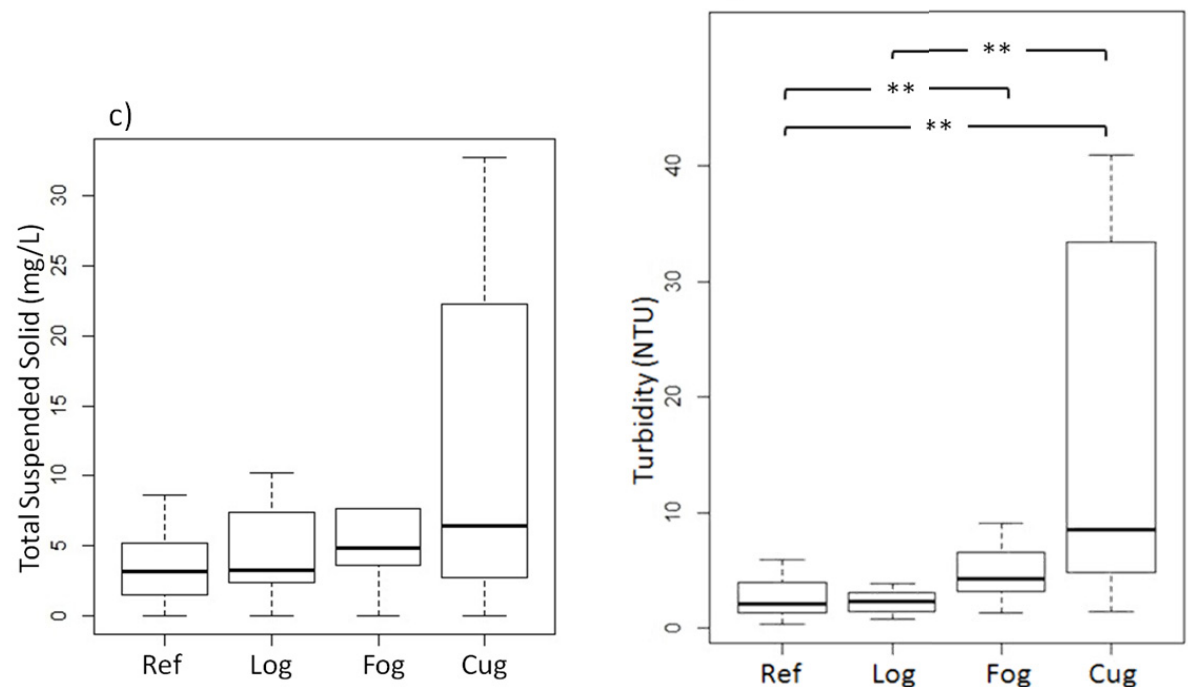

Figure 3

Boxplots of chemical variables (a) $\mathrm{PO}_{4}^{3-}(\mathrm{mg} / \mathrm{L})$, b) $\mathrm{NO}_{3}^{-}(\mathrm{mg} / \mathrm{L})$, c) Total Suspended Solid $(\mathrm{mg} / \mathrm{L})$ and d) turbidity (NTU)) in reference (Ref), logged (Log), formerly goldmined (Fog) and currently goldmined (Cug) sites. Limits of the box represent the first and third quartiles, bold line is the median, and whiskers are extreme values. Stars indicate the significance of Kruskal Wallis test between classes ${ }^{* *}: p$-value $\left.<0.05\right)$.

from values observed at reference and logged sites (see appendix I for outputs of Wilcoxon tests).

\section{DISCUSSION}

Given the contrasted types of human activities that affect stream ecosystems in FG, we expected significant differences in physical-chemical characteristics of impaired streams in relation to disturbance type.

Sites subjected to logging (deforestation) had finer bottom substrates than the reference sites. This can be related to increased inputs and deposits of fine particles, brought to the stream through tractor tracks and gravel road creation for logging trucks (Forman and Alexander, 1998). Such a tendency is triggered under equatorial climate, where harsh rains (rainy season) have a strong erosive effect on bare lands (Dudgeon, 2008). Despite increased siltation, suspended solids and water turbidity were not affected, highlighting the moderate effect of logging on streams in FG. It should be noted however that logging is strictly controlled in FG, 
in order to minimise environmental impacts. Specific measures include the absence of clearcutting, and the protection of the riparian zone where logging is forbidden. In the same way, logging trucks cannot be used during the rainy season and cannot cross streambeds, thus reducing sediment load to the aquatic ecosystems (Panchout, 2010). Such management efforts seem to prove efficient, as we did not detect any significant effect on turbidity and other chemical variables that are usually strongly sensitive to intensive logging activities. Specifically, leaching of soils and canopy opening are known to modify nitrogen and phosphorus fluxes to the aquatic ecosystem (Sweeney et al., 2004; Neill et al., 2006).

The river bottom of most gold mined sites was characterised by a dominance of gravels. This trend is not related to natural processes. Gold deposits are collected by washing the soils adjacent to the streams with high pressure water jets, and gravels are then sieved and released to the stream (Hinton et al., 2003), therefore increasing their prevalence over the streambed. During these operations, the streams also receive the draining water that contains a high load of sediments (Watts et al., 2003), explaining the higher turbidity at gold mined sites (see also Mol and Ouboter, 2004; Brosse et al., 2011).

Contrary to our expectation that gold mining, through the predicted clearing of the riparian forest and soil leaching, should increase stream eutrophication (see Hammond et al., 2007; Palmer et al., 2010), we did not find any significant change in nutrient loads $\left(\mathrm{PO}_{4}^{3-}\right.$ and $\left.\mathrm{NO}_{3}^{-}\right)$in gold mined sites. This result can be explained by the illegal nature of the exploited sites, which typically remain hidden under the canopy and do not host more than 30-40 workers (Hinton et al., 2003). There is therefore no deforestation at these sites, and hence no drastic shift in nutrient fluxes. This however does not mean that the ecosystem is not impaired. In particular, it has been demonstrated that both fish and diatom assemblages are strongly affected by the turbidity generated by small scale gold mining through habitat clogging and changes in light penetration over the bottom (Cleary, 1990; Mol and Ouboter, 2004; Brosse et al., 2011; Tudesque et al., 2012).

It is worth noting that turbidity remained significantly higher in formerly gold mined sites than in reference sites. This is probably due to fine sediment storage in the stream pools, so that these sediments can be re-suspended in the river column when river discharge increase during the frequent rain events. Therefore, temporary physical disturbances of stream ecosystems can persist in time, explaining why biological assemblages do not recover after stopping mining (e.g., fish and diatom, see Brosse et al., 2011; Tudesque et al., 2012).

Finally, the comparison of formerly and currently gold mined sites revealed a shift of activities towards the upstream sites. This might be afforded to two non-mutually exclusive reasons. First, the rarefaction of the gold resources as well as the rise of gold prices brought gold miners to move deeper in the forest (Cleary 1990; Hammond et al., 2007) and exploit more remote upstream sites. Second, the increased control of illegal gold mining by French authorities (Coppel et al., 1998) forces illegal miners to exploit those remote sites and to remain as inconspicuous as possible. This probably explains why in most of our sites we did not observe deforestation that would make the mining sites easily detected (Hinton et al., 2003).

In conclusion, we demonstrated that, under unimpacted conditions, there is no clear clustering of freshwater streams in French Guiana, thus complicating aims to set up a stream typology based on physical characteristics. Also, whatever the type of impact encountered in small streams of FG, nutrient concentrations did not prove relevant to measure human impacts. Logging did not result in detectable impacts on stream physical characteristics, probably because this type of activity is strictly managed and controlled by local stakeholders. However, site scale variables that describe the riverbed, habitat and suspended solids (i.e. simple physical measurements) clearly segregated both currently and formerly gold mined sites from reference sites. These results highlight the persisting, adverse effect of mining on the benthic habitat. Assuming that the structure of biological communities in streams are not due to random processes (Minshall and Petersen, 1985) but is strongly influenced by physical factors such as stream bed morphology (Wallace and Webster, 1996), hydrological conditions (Power et al., 1988), one can assume that substrate homogenization by anthropogenic activities will largely constraint the benthic community structure. Moreover, invertebrates or diatoms are 
tightly integrated into the structure and functioning of the benthic ecosystem, one may expect dramatic decreases in the biological quality of headwater streams with the shift of gold mining towards the upstream areas. To design potential biological indication tools of impairment, future research should thus aim at examining the match between physical-chemical and biological classifications of small streams under reference and impacted conditions.

\section{ACKNOWLEDGEMENTS}

This study was funded by the French Direction de l'Environnement, de l'Aménagement et du Logement de Guyane (DEAL Guyane), the French Office National de Eau et des Milieux Aquatiques (ONEMA) and the French Guiana Amazonian Park. ND is supported by two ANRTCIFRE grant $N^{\circ}$ 2011/0797 and $N^{\circ} 2011 / 0444$ SB and LA are supported by the Labex CEBA (ANR-10-LABX-25-01). We are also grateful to HYDRECO Guyane for logistic support and for technical support in the field.

\section{REFERENCES}

AFNOR, 2000. Qualité de l'eau. Détermination de la turbidité, NF EN ISO 7027, AFNOR Report, 11 p.

AFNOR, 2005a. Qualité de l'eau. Dosage des matières en suspension. Méthode par filtration sur filtre en fibres de verre, NF EN 872, AFNOR Report, $10 \mathrm{p}$.

AFNOR, 2005b. Qualité de l'eau. Dosage du phosphore. Méthode spectrométrique au molybdate d'ammonium, NF EN ISO 6878, AFNOR Report, 22 p.

Bailey R.C., Kennedy M.G., Dervish M.Z. and Taylor R.M., 1998. Biological assessment of freshwater ecosystems using a reference condition approach: comparing predicted and actual benthic invertebrate communities in Yukon streams. Freshwater Biol., 39, 765-774.

Bennett K.M.D., 2011. Watershed Urbanization Impacts to Headwater Streams in Northeastern Ohio, Ph.D. Thesis, Ohio State University.

Brosse S., Grenouillet G., Gevrey M., Khazraie K. and Tudesque L., 2011. Small-scale gold mining erodes fish assemblage structure in small neotropical streams. Biodivers. Conserv., 20,1013-1026.

Cleary D., 1990. Anatomy of the Amazon gold rush, Macmillan, Oxford, 245 p.

Coppel A., Gond V. and Allo S., 1998. Bilan de l'impact de l'orpaillage en Guyane. Une étude fondamentale, RDV techniques ONF, Report, $9 \mathrm{p}$.

Coquery M., Cossa D., Peretyazhko T., Azemard S. and Charlet T., 2003. Methylmercury formation in the anoxic waters of the Petit-Saut reservoir (French Guiana) and its spreading in the adjacent Sinnamary River. J. Phys. IV France, 107, 327-331.

De Jonge M., Van de Vijver B., Blust R. and Bervoets L., 2008. Responses of aquatic organisms to metal pollution in a lowland river in Flanders: a comparison of diatoms and macroinvertebrates. Sci. Tot. Environ., 407, 615-629.

Dudgeon D., 2008. Tropical Stream Ecology, Academic Press Elsevier, Netherlands, 370 p.

Durrieu G., Maury-Brachet R. and Boudou A., 2005. Goldmining and mercury contamination of the piscivorous fish Hoplias aimara in French Guiana (Amazon basin). Ecotox. Environ. Safe., 60, 315-323

Forman R.T. and Alexander L.E., 1998. Roads and their major ecological effects. Ann. Rev. Ecol. Syst., 29, 207-231.

Hammond D.S., Gond V., De Thoisy B., Forget P.M. and Dedijn B.P.E., 2007. Causes and consequences of a tropical forest gold rush in the Guiana Shield, South America. Ambio., 36, 661-670.

Hinton M., Veiga M., Tadeu A. and Veiga C., 2003. Clean artisanal gold mining: a utopian approach? J. Clean. Prod., 11, 99-115.

Maury-Brachet R., Durrieu G., Dominique Y. and Boudou A., 2006. Mercury distribution in fish organs and food regimes: Significant relationships from twelve species collected in French Guiana (Amazonian basin). Sci. Tot. Environ., 368 262-270.

Minshall, G.W., Cummins K.W., Petersen R.C., Cushing, C.E., Bruns D.A., Sedell J.R., and Vannote R.L., 1985. Developments in stream ecosystem theory. Can. J. Fish. Aquat. Sci., 42, 1045-1055. 
Mol J.H. and Ouboter P.E., 2004. Downstream effects of erosion from small-scale gold mining on the instream habitat and fish community of a small neotropical forest stream. Conserv. Biol., 18, 201-214.

Neill C., Deegan L.A., Thomas S.M., Haupert C.L., Krusche A.V. Ballester V.M. and Victoria A.V., 2006. Deforestation alters the hydraulic and biogeochemical characteristics of small lowland Amazonian streams. Hydrol. Process, 20, 2563-2580.

Oksanen J., Blanchet F.G., Kindt R., Legendre P., Minchin P.R., O’Hara R.B., Simpson G.L., Solymos P., Henry M., Stevens H. and Wagner H., 2013. Vegan: Community Ecology Package. R package version 2.0-7. Available at: http://CRAN.R-project.org/package=vegan.

Palmer M.A., Bernhardt E.S., Schlesinger W.H., Eshleman K.N., Foufoula-Georgiou E., Hendryx M.S., Lemly A.D., Likens G.E., Loucks O.L., Power M.E., White P.S. and Wilcock P.R., 2010. Mountaintop mining consequences. Science, 327, 148-149.

Panchout J., 2010. Charte de l'exploitation forestière à faible impact en Guyane. Direction Régionale de I'ONF Guyane, Fonds Européen Agricole pour le Développement Rural (FEADER), 77 p.

Pfeiffer W.C., Lacerda L.D., Malm O., Souza C.M.M., Silveira E.G. and Bastos W.R.,1989. Mercury concentrations in inland waters of gold mining areas in Rondônia, Brazil. Sci. Tot. Environ., 87, 233-240.

Power M.E., Stout R.J., Cushing C.E., Harper P.P., Hauer F.R., Matthews W.J., and De Badgen W., 1988. Biotic and abiotic controls in river and stream communities. J.N. Am. Benthol. Soc., 7, 456-479.

Roulet M., Lucotte M., Farella N., Serique G., Coelho H., Sousa Passos C.J., Jesus da Silva E., Scavone de Andrade P., Mergler D., Guimaraes J.R.D. and Amorim M., 1999. Effects of recent human colonization on the presence of mercury in Amazonian ecosystems. Water, Air, Soil Pollution, 112, 297-313.

Souchon Y., Andriamahéfa H., Cohen P., Breil P., Pella H., Lamouroux N., Malavoi J.R. and Wasson J.G., 2000. Régionalisation de l'habitat aquatique dans le bassin de la Loire, Rapport Agence de l'eau Loire - Bretagne, Report, 297 p.

Sweeney B.W., Bott T.L., Jackson J.K., Kaplan L.A., Newbold J.D., Standley L.J., Hession W.C. and Horwitz R.J., 2004. Riparian deforestation, stream narrowing, and loss of stream ecosystem services. Proc. Natl. Acad. Sci., 39, 14132-14137.

Thioulouse J., Chessel D., Dolédec S. and Olivier J.M., 1997. ADE-4: a multivariate analysis and graphical display software. Stat. Comput., 7, 75-83.

Touron-Poncet H., Bernadet C., Compin A., Bargier N., and Céréghino, R., 2014. Implementing the Water Framework Directive in overseas Europe: A multimetric macroinvertebrate index for river bioassessment in Caribbean islands. Limnologica, 47, 34-43.

Tudesque L., Gevrey M., Grenouillet G. and Lek S., 2008. Long-term changes in water physicochemistry in the Adour-Garonne hydrographic network during the last three decades. Water Res., 42, 732-742.

Tudesque L., Grenouillet G., Gevrey M. Khazraie K. and Brosse S., 2012. Influence of small-scale gold mining on French Guiana streams: Are diatoms assemblages valid disturbance sensors? Ecol. Indic., 14 100-106.

Van Sickle J. and Hughes R.M., 2000. Classification strengths of ecoregions, catchments, and geographic clusters for aquatic vertebrates in Oregon. J.N. Am. Benthol. Soc., 19, 370-384.

Waite I.R. and Carpenter K.D., 2000. Associations among fish assemblage structure and environmental variables in Willamette Basin streams, Oregon. T. Am. Fish. Soc., 129, 754-770.

Wallace J.B., and Webster J.R., 1996. The role of macroinvertebrates in stream ecosystem function. Annu. Rev. Entomol., 41, 115-139.

Watts C.W., Tolhurst T.J., Black K.S., and Whitmore A.P., 2003. In situ measurements of erosion shear stress and geotechnical shear strength of the intertidal sediments of the experimental managed realignment scheme at Tollesbury, Essex, UK. Estuar. Coast. Shelf S., 58, 611-620. 